\title{
Phenological Features of (Mamestra Brassicae L. 1758) Development in Agrocoenosis of Cabbage in the Kamin-Kashyrskyi District (Volyn Region, Ukraine) \\ I.YA. Truskavetska
}

\author{
Pereiaslav-Khmelnytskyi Hryhorii Skovoroda State Pedagogical University, Pereiaslav Khmelnytskyi, Ukraine. \\ E-mail: irina-truskaveckaya@ukr.net
}

Received: 09.08.2019. Accepted: 09.09.2019

\begin{abstract}
The animal world of Ukraine is characterized by a large variety of species. Among the lepidoptera there are a lot of pests whose larvae cause significant damage to agriculture. In the paper, we investigated the seasonal and perennial dynamics of vegetable crops pests' population of Mamestra brassicae in the agrobiocenoses of white cabbage. The basis of our study was the investigation of the relative quantity of the pest larvae, we demonstrated the damage to plants, as well as the periods of intensive emergence of the imago and the number of generations per year. In future, this will enable the development of effective ecologically sound methods for controlling the number of species of white cabbage pests in the conditions of Kamin-Kashyrskyi district of Volyn region. Kamin-Kashyrskyi area has a flat terrain and is characterized by a warm temperate continental climate with sufficient amount of moisture, the presence of impoverished sod-podzolic soils. The area is mostly plain, with large marsh massifs, which are favorable conditions for the existence of Mamestra brassicae, as this species is moisture-loving. Observation of biocenotic connections in the agrobiocenoses of white cabbage and stationary research on the development of protection, testing and implementation systems was carried out during 2017-2018 at the garden sites of Kamin-Kashirsky district during the entire vegetation period of the plants. White cabbage is damaged throughout the period of vegetation, however, the damage that appear after emergence of seedlings and planting of seedlings into the soil are dangerous due to their consequences. In the second half of summer and in autumn, the larvae of Mamestra brassicae caused significant damage to cabbage plants in the gardens of Novi Chervyshcha. Within this area, Mamestra brassicae develops two generations per year, causing tangible damage to the agrocoenosis of cabbage of different sowing dates. The contamination of cabbage by the larva of the first and second generations approximately accounts to $24 \%$, where $2-3$ larvae live on one plant. The massive emergence of the imago occurs in the middle of May the first half of June while the average daily temperature is $+20^{\circ} \mathrm{C}$ to $+22^{\circ} \mathrm{C}$. The first egg laying was recorded at the end of May, which the female lays in groups, 20-80 units on the underside of the leaves, and the embryonic development lasts 6 to 8 days. Pupae hibernate in the soil, at a depth of $8-12 \mathrm{~cm}$. Significant damage to white cabbage plants was caused by the larvae of the first generation in June and early July, and of the second generation in August and early September. They intensively feed at night and at dawn, and in the daytime there is a decline in mobility and nutritional activity. Second-generation larvae often bite into cabbage heads where they make holes and pollute them with their liquid excrement, which leads to a decrease in crops. The use of microbiological drugs Dimilin and Insehar are some of the most effective ways to get rid of Lepidoptera, including larvae of Mamestra brassicae, which provide protection of cabbage plants by $93-97 \%$.
\end{abstract}

Keywords: Cabbage moth; larvae; embryonic development; egg layin; imago emergence; white cabbage

\section{Introduction}

The question of studying the species composition and dynamics of the number of Lepidoptera pests of white cabbage in Kamin-Kashyrskyi area is relevant in the present time. In Ukraine, white cabbage occupies one of the leading roles among vegetable crops, both in cultivating areas size and in the consumption by population. Cabbage is a very cold-resistant culture. The young crops withstand frosts to $6^{\circ} \mathrm{C}-8^{\circ} \mathrm{C}$. One of the biological peculiarities of cabbage is extraordinary need of moisture. Therefore, it produces high crops in areas with sufficient or excessive amount of moisture and irrigated land, which is a favorable condition for the existence of Mamestra brassicae vegetable pest.

The wide range of distribution and high harmfulness of the Lepidoptera has led us to conduct research in the southwestern part of Polissya, namely the Kamin-Kashyrskyi district. Getting high quality cabbage crops is impossible without the timely application of measures that protect it from harmful insects, including Mamestra brassicae. In this regard, the improvement of methods for determining the state of populations of Mamestra brassicae as a basis for predicting the degree of pests threat to cabbage of Volyn region has significant practical value (Beleckij, 2011). The aim of the study is to find out the phenological features of the seasonal dynamics of Mamestra Brassicae in the agrocentoses of white cabbage in Kamyn-Kashirsky district.

A number of native and foreign scientists engaged in the study of phenological characteristics, the dynamics of the number, harmfulness and the prevalence of Lepidoptera pests of vegetable crops, cabbage in particular (Drozda, 2000). For the first time, information on the peculiarities of biology, distribution, harmfulness of Mamestra brassicae is given in S.M. Vasiliev's and M. M. Bogdanova-Katkova's works (Serous, 2000). The researchers noted that Mamestra brassicae is distributed throughout Central and Southern Europe and in many other countries, with the exception of the Far North and desert areas of Central Asia. According to the results of V.I. Stepanin Mamestra brassicae larvae severely damage the white cabbage and cauliflower, less red cabbage and do not affect turnip-rooted cabbage, and V.I. Tsybulko argues (Tsybulko, 2012) that from 30 to $50 \%$ of the second-generation larvae bite into the cabbage and make it unsuitable for consumption. According to the results of the research by Ponomarenko S.V., mass pest reproduction in Ukraine began in 1871 and has been intensively developing for 7 years (Ponomarenko, 2013). 


\section{Materials and Methods}

Experimental research was carried out in the southwestern part of Polissya of Ukraine on the territory of Volyn region (Kamin-Kashirsky district) during 2017-2018 on the late varieties of cabbage "Amager 611", "Snow White" and "Ukrainian Autumn". Mamestra brassicae is a moistureloving species, found in areas with high humidity. The seasonal dynamics of the development of Mamestra brassicae was studied in the gardens of the village of Novy Chervysh throughout the vegetative period of white cabbage.

The calculations of the dynamics of Mamestra brassicae in cabbage agrocoenosis were conducted in accordance with the generally accepted methods by Tryapitsina, Shapiro and Schepetylnikova (Trjapicyn, Shapiro, Shhepetilnikova, 1965). For prediction of cabbage pests we used approaches by Bondarenko, Yakovenko, Meshkova (Yermolenko, 1971) and Biletsky (2011) and others. Types of insects, both harmful and useful, were determined with the help of the determinant by Yermolenko.

Cabbage plantations were inspected two weeks after planting; in the phase of rosette; during the formation of the head; 2 weeks before harvesting and during harvesting. We counted pests on stationary areas during the growing season of cabbage, each of the areas contained 100 plants (10 plants in 10 places each ten days). The larvae of Mamestra brassicae were counted on three varieties of cabbage on leaves and heads. For the recording and catching of night insects, we used pheromone and light traps, the principle of which is that insects at night actively fly to the source of light, where they are neutralized. These observations established the beginning insects emergence and its dynamics (Likar, 2000).

The absolute density of the population was determined by the number of individuals of a certain species per plant, the relative density of the population (occupation density of plants) was determined as the proportion of populated plants, expressed as a percentage. The reproduction factor was calculated by the ratio of the absolute density of the population at the experimental site in the current and previous year. The distribution coefficient of pests was determined by the ratio of the relative density of the population at the site in the current and previous year (Serous, 2000).

\section{Results and Discussion}

As a result of our observations, on the territory of Kamin- Kashyrsky area in 2017-2018 experimental sites in agrocentoses of cabbage Amager 611, Snow White and Ukrainian Autumn were dominated by a complex of Lepidoptera plant feeders, among which the Mamestra brassicae larvae severely damaged the plants.

Mamestra brassicae is a night insect with wings of 40-50 mm, front wings are dark brown with a yellowish-white wavy line, which forms two escallops in the middle of the wing, and two dark spots are at the front edge, the rear wings are gray, with the darker edges (Belecki, 2011).

During the year, two generations develop, imago emergence occurs from May to September. The insects are active in the twilight period, especially from 10 pm until midnight. Dynamics of cabbage moth emergence of 1st and 2nd generations are presented in Table 1 and Table 2.

Table 1. Seasonal dynamics of the emergence of the first generation of Mamestra brassicae in the Kamin-Kashirskyi district, $2017-2018$.

\begin{tabular}{llllllllllll}
\hline Years & \multicolumn{1}{c}{ Number of butterflies in $\mathbf{5}$ days, insects per trap } \\
& 15.05 & 20.05 & 25.05 & 30.05 & 5.06 & 10.06 & 15.06 & 20.06 & 25.06 & 30.06 & total \\
2017 & $4 / 1$ & $22 / 4$ & $39 / 6$ & $55 / 7$ & $44 / 5$ & $31 / 6$ & $30 / 4$ & $15 / 2$ & $9 / 0$ & $4 / 0$ & $253 / 35$ \\
2018 & $0 / 0$ & $23 / 2$ & $38 / 6$ & $59 / 8$ & $49 / 9$ & $47 / 2$ & $39 / 3$ & $13 / 0$ & $19 / 0$ & $4 / 0$ & $288 / 30$ \\
average & $2 / 1$ & $22 / 3$ & $38 / 6$ & $57 / 7$ & $46 / 7$ & $39 / 4$ & $34 / 6$ & $14 / 1$ & $14 / 0$ & $4 / 0$ & $270 / 32$ \\
\hline
\end{tabular}

Table 2. The season dynamics of Mamestra brassicae cabbage moth emergence of second generation, Kamin-Kashyrskyi district, $2017-2018$.

\begin{tabular}{|c|c|c|c|c|c|c|c|c|c|c|c|c|c|}
\hline \multirow[t]{2}{*}{ Years } & \multicolumn{12}{|c|}{ Number of butterflies in 5 days, insects per trap } & \multirow[t]{2}{*}{ Total } \\
\hline & ' & & & ; & : & : & i & i & 1 & 1 & 15.09 & 20.09 & \\
\hline 2017 & $17 / 2$ & $22 / 7$ & $41 / 9$ & $33 / 10$ & $19 / 3$ & $22 / 3$ & $14 / 0$ & $9 / 1$ & $7 / 0$ & $7 / 1$ & $3 / 0$ & $0 / 0$ & $187 / 39$ \\
\hline 2018 & $9 / 9$ & $23 / 5$ & $34 / 9$ & $42 / 3$ & $47 / 4$ & $38 / 4$ & $19 / 0$ & $16 / 1$ & $12 / 0$ & $11 / 1$ & $8 / 0$ & $2 / 0$ & $261 / 36$ \\
\hline average & $13 / 5$ & $22 / 6$ & $37 / 9$ & $37 / 6$ & $33 / 3$ & $30 / 3$ & $16 / 0$ & $5 / 1$ & $\ni / 0$ & $9 / 1$ & $6 / 0$ & $1 / 0$ & $224 / 37$ \\
\hline
\end{tabular}

Note: the numerator is the number of butterflies in total denominator is the number of males.

As a result, the data show that the Mamestra brassicae emergence of pupae which lived after winter lasts from the middle of May to the end of June. The maximum emergence of the second generation imago is observed in the first half of August, with an average daily temperature of +23 $0^{\circ} \mathrm{C}$ to $+24^{\circ} \mathrm{C}$. During 2017 , the conditions of this region were dominated by the female Mamestra brassicae, which led to massive breeding of the pest, an increase in their number next year, as well as a decrease in crops from the family Brassicaceae, including white cabbage. Distribution ratio of Mamestra brassicae of the 1 and 2 generations in 2018 is by $12.9 \%$ more in comparison with 2017. The first egg laying of Mamestra brassicae were marked on May 27, 2017 and on April 24, 2018, whose embryonic development lasted 9-10 days. The larvae of the first generation were detected in early June (06.06.2017, and 02.06.2018) (Table 3). At first, they hold together, have a gray-green color and bite small holes in the leaves bottoms. According to our observations, the lifespan of larvae of the first generation is $24-25$ days, and they start pupae phase at the end of June. (30.06.2017 to 27.06.2018). The pupae phase lasts 26-28 days and in the end of July the beginning of August you can meet the second generation of insects.

Table 3. Terms of Mamestra brassicae development on cabbage varieties (gardens of Novi Chervyshcha village, 2017-2018).

\begin{tabular}{lllll}
\hline Year & \multicolumn{2}{l}{ Terms of the pest development } \\
Emergence Indicators & First egg laying & First larva hatching & Beginn \\
$\begin{array}{llll}\text { 1st generation } \\
2017\end{array}$ & & & \\
2018 & 19.05 & 27.05 & 06.06 & 30.06 \\
2nd generation & 14.05 & 24.05 & 02.06 & 26.06 \\
2017 & 28.07 & & & \\
2018 & 30.07 & 02.08 & 26.08 & 23.09 \\
\end{tabular}


The mass rebirth of larvae of the next generation took place in the second half of August $(08.26 .2017,08.29 .2018)$, whose development lasted 20-24 days. At this stage, the larvae are dark in color, and on the sides of the body they have a wide yellow stripe, they distribute on cabbage plants, they bite the leaves leaving uneven holes, only the parts of leaves are left, because they eat out deep holes, there the pests leave their excrements. Damaged cabbage heads are unsuitable for storage and consumption. The start of pupae phase of the second generation occurs at the end of June (23.09. 2017 and 09.28.2018).

In the course of the research we conducted the following pattern has been found: the more weeds are near the investigated area, the greater the number of eggs during egg laying. In our opinion, this is due to the fact that the flowers from the weeds create additional nutrition for the imago necessary for maturation of the sexual products.

During 2017-2018 phytophages in the garden areas of the village of Novi Chervyshcha in agrocentoses of white cabbage populate an average of $24 \%$ of plants, the density of larvae is $2-5$ insects per plant. Since vegetable products are used during the year in fresh form, the protection of cabbage plants should be based on increasing the effectiveness of natural factors due to the use of optimal methods of agrotechnics and the use of environmentally friendly means of protection.

In order to increase the crop and improve the quality of the products, during the growing of plants, we studied the effectiveness of Insegar and Dymilin. On the plots (area of each is 0.15 hectares) Amaher 116, Snow White and Ukrainian Autumn, cabbage there were two treatments at intervals of 15 days with the rate of consumption of Dymilin $0.3 \mathrm{~kg} / \mathrm{ha}$, and Insegar $-0.2 \mathrm{~kg} / \mathrm{ha}$ (Table 4).

Table 4. Biological effectiveness of Insegar and Dymilin on larvae Mamestra brassicae on plants of cabbage.

\begin{tabular}{|c|c|c|c|c|c|}
\hline \multirow[t]{2}{*}{ No. } & \multirow[t]{2}{*}{ Version } & \multirow[t]{2}{*}{ Number of larvae } & \multicolumn{2}{|c|}{ Biological effectiveness,\% } & \multirow[t]{2}{*}{ Average } \\
\hline & & & 2017 & 2018 & \\
\hline 1 & Dymilin-0,3 kg / ha & 50 & 93 & 92 & 93 \\
\hline 2 & Insegar-0.2 kg / ha & 50 & 98 & 96 & 97 \\
\hline 3 & Control & 50 & 14 & 17 & 15.5 \\
\hline
\end{tabular}

Note: the average (15.5) is the natural loss of larvae.

During the period of our observations, the efficiency of Dymilin and Insegar was high, at the same time, we could not achieve a long-term reduction in the number of pests in the limited areas of experimental sites, which in our opinion is due to migrations of insects from control sites. On the cabbage treated with Insegar, there was no increase in the number of other pests.

\section{Conclusion}

Research over the years 2017-2018 shows that in the conditions of south-western Polissya of Ukraine, of Kamin-Kashyrskyi district of Volyn region of the village of Novi Chervyshcha, vegetable crops, in particular late varieties of white cabbage are intensively populated by larvae Mamestra brassicae. On the cabbage of late harvesting terms Mamestra brassicae developed in two generations. The greatest harm to cabbage plants in the garden areas of Kamin-Kashyrskyi dictrict was caused by larvae of the second generation in the second half of June and the second (end of August-September). The infestation of cabbage plants by larvae of the first and second generations in average was $24 \%$, the density of larvae is 25 insects per plant. The larvae of Lepidoptera pests in agrocoenosis of white cabbage inflicted the greatest damage to the cabbage variety Amager 116 (53\%), and the smallest to Ukrainian autumn (33.5\%). The intense emergence of pupae, which lived after winter, began in the second half of May in 2017 and 2018. Distribution coefficient of Mamestra brassicae in 2018 is by $12.9 \%$ higher compared to 2017. The results of record-keeping in stationary areas showed high effectiveness of Dimilin and Insegar on Lepidoptera. Two-time treatment with Insegar in the period of mass appearance of Lepidoptera larvae reduces their number by $97 \%$, and Dimilin - $93 \%$.

\section{References}

Beleckij, E.N. (2011). Massive reproduction of insects. History, theory, forecasting: studying manual. Harkov: Majdan, 172.

Drozda, V.F. (2000). Criteria for assessing the physiological status of populations Mamestra brassicae of (Lepidoptera, Noctuidae) and cabbage pest Pieris brassicae (Lepidoptera, Pierida). Protection and quarantine of plants, 46, 16-22.

Yermolenko, V.N., Kliuchko Z.V. (1971). Key to insects: guide. Kyiv: Radianska shkola, 177.

Kolesnik, L. I. (2003). Monitoring of Lepidoptera pests on white cabbage and its biological protection. Ovochivnytstvo i bashtannytstvo. Kharkiv, 48, 222-225.

Likar, Ya.O. (2000). The role of entomophages in limiting the number of Lepidoptera pests in crop agrocoenosis. Visnyk. Poltavskyi derzhavnyi silskohospodarskyi instytut, 2, 15-18.

Ponomarenko, S.V. (2012). Features of development of Mamestra brassicae on white cabbage in Poltava area. Visnyk Poltavskoi derzhavnoi ahrarnoi akademii, 3, 159-161.

Serous, L. Ja. (2000). Characteristics of mass reproductions of Mamestra brassicacea L. in Ukraine. Visnyk KhNAU, seriia Entomolohiia ta fitopatolohiia, 3, 174-177.

Stepanin, V. I. (1973). Mamestra brassicae in Krasnodar region and the use of biological means against it. avtor. dis, kand. biol. nauk: spec. 03.00.09 Jentomologija. Krasnodar, 21.

Trjapicyn, V.A. (1965). Shapiro V.A., Shhepetil'nikova V.A. Vermins and predators of agricultural plants. ucheb. posob. Leningrad. Izd-vo Kolos, $152 \mathrm{p}$.

Tsybulko, V. I. (1972). Main leafeating pests of cabbage and the basics of the integrated fight against them in Kharkov area: avtoref. dis. kand. biol. nauk. spec. 03.00.09 Jentomologija. Har'kov, 24.

Citation: Truskavetska, I.YA. (2019). Phenological Features of (Mamestra Brassicae L. 1758) Development in Agrocoenosis of Cabbage in the Kamin-Kashyrskyi District (Volyn Region, Ukraine). Ukrainian Journal of Ecology, 9(3), 71-73.

(cc) EY This work is licensed under a Creative Commons Attribution 4.0. License 